\title{
WORKSHOP (PELATIHAN) PEMBUATAN PROPOSAL "PENELITIAN QUASI EKSPERIMEN" BAGI GURU DAN CALON GURU DAN BUDIDAYA IKAN LELE BAGI MASYARAKAT RANGKA MENINGKATKAN PENDAPATAN UNTUK KESEJAHTERAAN DI KELUARAHAN MEKARSARI, KECAMATAN JATISARI, KABUPATEN KARAWANG, PROVINSI JAWA BARAT
}

\author{
Etin Solihatin $^{1}$, Roby Ibnu Syarifain ${ }^{2}$, Raharjo $^{1}$, Esa Aryo Kuncoro ${ }^{1}$, Alwi $^{1}$ \\ Universitas Negeri Jakarta ${ }^{1}$, Universitas Padjadjaran ${ }^{2}$ \\ Email:dr.etinsolihatin@gmail.com
}

\begin{abstract}
The purposes of devotion to the community activities are to develop teacher and teacher candidate ability to create research draft proposals, also Catfish cultivation using biofloc technique. Proposal making workshop activities consist of providing information, practice, and intensive consultation. Catfish cultivation activities consist of cultivation practice, marketing, and simple accountancy record, also evaluation. Based on those activities proposal making workshop was able to improve teacher and teacher candidates ability to create a quasi-experiment proposal final draft. Activity documentation and material were published on the YouTube platform https://www.youtube.com/watch?v=ogfgRQJUE7w. While catfish cultivation with biofloc technique is able to to improve community income because catfish could be harvested after three months and sold. Catfish cultivation can increase community prosperity in the COVID-19 pandemic because it could produce alternative income through the primary sector (food). Activity documentation was published on the YouTube platform https://m.youtube. com/ watch?v=G542rOJuzrc.
\end{abstract}

Keywords: Catfish cultivation; income improvement; quasi experiment; workshop

\begin{abstract}
Abstrak
Kegiatan pengabdian ini bertujuan untuk meningkatkan kemampuan guru/ calon guru dalam membuat draft proposal penelitian quasi eksperimen dan pengenalan budidaya lele sistem bioflock. Pelaksanaan workshop pembuatan proposal dilakukan melalui pemberian informasi, praktek dan pendampingan konsultasi yang intensif. Budidaya ikan lele sistem bioflik diaksanakan melalui berbagi pendapat dan praktik budidaya yang diikuti dengan kegiatan pemasaran, pembukuan sederhana, dan evaluasi kegiatan. Berdasarkan hasil pengabdian dapat disimpulkan bahwa workshop/ pelatihan pembuatan proposal penelitian Quasi eksperimen dapat meningkatkan kemampuan guru/ calon guru dalam membuat proposal penelitian. Dokumentasi kegiatan dan QR Code materi pembuatan proposal dapat dilihat pada platform YouTube https://www.youtube.com/watch?v=ogfgRQJUE7w. Setelah itu, budidaya ikan lele teknik bioflock dapat meningkatkan pendapatan masyarakat karena dalam waktu + tiga bulan ikan dapat dipanen, dan dijual. Hal ini akan berdampak pada peningkatan kesejahteraan di masa pandemi yang identik dengan tingginya angka PHK. Berdadarkan hal tersebut penghasilan alternatif dapat menjadi solusi menjaga kesejahteraan ekonomi di tengah masa pandemi. Dokumentasi kegiatan dan langkah budidaya lele dapat dilihat pada platform YouTube https://m.youtube.com/watch?v=G542rOJuzrc.
\end{abstract}

Kata Kunci: Budidaya ikan lele; quasi eksperimen; peningkatan pendapatan; workshop 


\section{PENDAHULUAN}

Berdasarkan renstra pengabdian kepada masyarakat tahun 2021-2025, lokasi pengabdian berjarak $200 \mathrm{~km}$ dari kampus UNJ. Untuk itu tim pengabdian kepada masyarakat memilih lokasi di Desa Mekarsari, Kecamatan Jatisari, Kabupaten Karawang. pertama lokasi ini dipilih dengan didasari hasil observasi awal dan wawancara dengan guru, calon guru, dan mahasiswa yang menghendaki adanya penyegaran mengenai pembuatan "proposal penelitian quasi eksperimen" sebagai kelanjutan dari workshop "Penelitian Tindakan Kelas". Harapan yang hendak diraih adalah mereka dapat melaksanakan tugasnya sebagai pendidik, yang diintegrasikan dengan penelitian sesuai permasalahan yang ditemukan di kelas saat pandemi Covid-19 berakhir. Kedua, berdasarkan observasi awal dan wawancara dengan Kepala Desa Mekarsari dan masyarakat, masyarakat membutuhkan pelatihan dalam budidaya ikan lele untuk meningkatkan pendapatan yang menurun sebagai akibat dari pandemi Covid-19 dan bahkan pada beberapa kasus hingga tidak memiliki pendapatan dikarenakan terkena pemutusan hubungan kerja dikarenakan banyak perusahaan yang melakukan pengurangan jumlah karyawan sebagai akibat menurunnya daya beli pasar. Disamping itu, ikan lele merupakan jenis ikan yang relatif adaptif terhadap kondisi lingkungan dibanding dengan ikan mas dan memiliki permintaan pasar yang relatif stabil. Hal ini mengisyaratkan potensi jika masyarakat dilatih dalam budidaya ikan lele dan berhasil, maka sektor ini menjadi sektor yang menjanjikan untuk memperoleh pendapatan. Hal ini mengindikasikan bahwa produk dan pemasarannya sudah disurvei dengan baik. Untuk pengairannya tersedia dengan baik karena Desa Mekarsari dilewati oleh aliran Tarum Timur. Ditinjau dari segi sosial, warga desa relatif kompak dan rukun, serta kondisi desa yang relatif aman dari tindakan kriminal karena terdapat banyak pesantren dan pengajian, sehingga masyarakat umumnya relatif memiliki ketaatan agama dan hukum yang baik.

Sebagai lembaga Pendidikan Tinggi Negeri, Universitas Negeri Jakarta mengemban amanah untuk merealisasikan Tri Dharma perguruan Tinggi, yaitu pendidikan, penelitian, dan pengabdian kepada masyarakat. Melalui ketiga unsur ini Universitas Negeri Jakarta diharapkan dapat memberikan kontribusi positif dan kontinu dalam berbagai aspek pengembangan bidang pendidikan salah satu di antaranya melakukan workshop/ pelatihan pembuatan proposal Quasi Ekspermen, sebagai kelanjutan dari pelatihan PTK (penelitian Tindakan Kelas) terdahulu.

Kegiatan pengabdian kepada masyarakat ini memiliki tujuan sebagai berikut:

1) Meningkatkan pengetahuan dan pemahaman bagi guru dan calon guru mengenai proposal penelitian Quasi Eksperimen. 
2) Meningkatkan kemampuan (skill) pembuatan proposal penelitian Quasi Eksperimen.

3) Meningkatkan pengetahuan dan pemahaman bagi masyarakat tentang budidaya ikan lele.

4) Meningkatkan keterampilan tentang budidaya ikan lele dalam rangka meningkatkan pendapatan dan kesejahteraan masyarakat.

Adapun manfaat kegiatan pengabdian masyarakat yaitu:

1) Diharapkan agar guru dan calon guru memiliki pengetahuan dan pemahaman tentang penelitian Quasi Eksperimen.

2) Adanya peningkatan kemampuan (skill) pembuatan proposal penelitian Quasi Eksperimen.

3) Adanya peningkatan pengetahuan dan pemahaman bagi masyarakat tentang budidaya ikan lele

4) Adanya peningkatan keterampilan tentang budidaya ikan lele, dalam rangka meningkatkan pendapatan masyarakat untuk kesejahteraan.

\section{Permasalahan Mitra}

Adapun permasalahan mitra yang telah disepakati untuk dicarikan solusinya bersama Tim Pengabdian Kepada Masyarakat dari segi pendidikan dan kehidupan masyarakat yaitu:

1) Bagaimana meningkatkan kemampuan guru dan calon guru dalam membuat proposal penelitian Quasi Eksperimen?
2) Bagaimana meningkatkan pendapatan masyarakat melalui keterampilan budidaya ikan lele? Kegiatan ini memiliki dua buah tujuan. Tujuan pertama dari kegiatan ini untuk meningkatkan kemampuan guru/ calon guru dalam membuat draft proposal penelitian. Hal ini dilakukan melalui pemberian informasi dan praktek, serta pendampingan/konsultasi yang intensif. Tujuan kedua yaitu meningkatkan kemampuan masyarakat dalam melakukan budidaya ikan lele guna meningkatkan pendapatan untuk kesejahteraan masyarakat.

\section{TINJAUAN LITERATUR}

\section{Penelitian Quasi Eksperimen}

Penelitian eksperimental

(Experimental Research) merupakan penelitian yang bertujuan untuk menilai pengaruh suat perlakuan/ tindakan/ treatment/ pendidikan terhadap tingkah laku peserta didik, atau menguji hipotesis, tentang ada tidaknya pengaruh tindakan yang dilakukan bila dibandingkan dengan tindakan lain. Penelitian kuantitatif merupakan metode-metode untuk menguji teoriteori tertentu dengan cara meneliti hubungan antar variabel (Cresswell 2017). Pada penelitian eksperimen data dikumpulkan dan dianalisis menggunakan aturan statistik, sehingga menghasilkan simpulan yang kuat dan objektif (Montgomery 2012).

Penelitian eksperimen berusaha menentukan apakah suatu treatment mempengaruhi sebuah hasil penelitian. Pengaruh ini dinilai dengan cara menerapkan treatment tertentu pada 
suatu kelompok yang sering disebut kelompok treatment, dan tidak menerapkan pada kelompok lain yang dikategorikan dengan kelompok kontrol.

Selanjutnya penentuan bagaimana menentukan hasil akhir dua kelompok tersebut. Penelitian ini mencakup eksperimen aktual dengan penugasan acak (Random Assignment) atas subjeksubjek yang diberi perlakuan dalam kondisi tertentu, dan quasi eksperimen dengan prosedur-prosedur non acak (Maciejewski 2020).

Penelitian eksperimen memiliki ciri khusus seperti:

1) Adanya perlakuan yang diberikan secara sengaja untuk diamati akibatnya.

2) Dilakukan pengendalian variabel-variabel selain variabel perlakuan yang dapat secara jelas memperoleh gambaran tentang hasil dari pelaksanaan yang diberikan.

3) Dimungkinkan mengadakan pengubahan (manipulasi) variabel perlakuan bila diinginkan oleh peneliti untuk mengamati lebih cermat akibat perlakuan tersebut.

Tujuan utama eksperimen adalah untuk menilai bagaimana pengaruh treatment terhadap sifat suat populasi tertentu atau untuk menguji hipotesis tentang ada tidaknya pengaruh treatment.

Quasi Experiment atau eksperimen semu, mengingat sampel yang diteliti adalah manusia/ peserta didik, maka mereka tidak bisa steril dari lingkungan. Berbeda dengan eksperimen yang dilakukan di laboratorium, sehingga tidak terkontaminasi lingkungan.

Beberapa contoh penelitian yang menggunakan Quasi Experiment:

1) Pengaruh Pembelajaran Berbatuan Geogebra terhadap Pemahaman Konsep Matematis ditinjau dari Gaya Kognitif (Purwanti et al., 2016)

2) Pelatihan Komunikasi Efektif untuk Meningkatkan Efikasi Diri Perawat dalam Pelaksanaan Identifikasi Pasien (Simamora 2020).

3) Pembelajaran Learning Cycle $5 E$ berbantuan Geogebra terhadap Kemampuan Pemahaman Konsep Matematis (Pratiwi 2016).

4) Pengaruh Teknik Diskusi Kelompok Dalam Bimbingan Kelompok Terhadap Peningkatan Pemahaman Siswa Tentang Dimensi Seksualitas Manusia (Mulyani et al., 2016).

Solusi permasalahan kedua tentang bagaimana meningkatkan keterampilan budidaya ikan lele dalam rangka meningkatkan pendapatan masyarakat untuk kesejahteraan?

1) Diadakan diskusi/ sharing pendapat untuk penyegaran pemahaman tentang budidaya ikan lele, pembagian tugas dan tanggung jawab.

2) Pembuatan kolam ikan lele secara bersama-sama dari bahan terpal yang kuat, secara berderet. Pembuatan kolam berderet dilakukan untuk memudahkan pengontrolan di tahap awal, agar 
produksi sesuai harapan, ditambah doa bersama.

3) Pembelian terpal kualitas baik melalui marketplace, bibit ikan lele ukuran7-8, pembelian pakan ikan lele sesuai umur ikan lele, pembelian bambu/ besi, kawat/ tambang untuk mengikat, dan paralon. Pembelian alat-alat ini dilakukan secara transparan, agar selanjutnya masyarakat bisa secara mandiri membelinya di kemudian hari, dan melatih manajemen secara benar dan transparan.

4) Setelah lele berumur \pm tiga bulan maka ikan lele dapat dipanen dengan ukuran 8 ekor per $\mathrm{kg}$ dan dijual ke pasar, pengepul, ataupun dipasarkan langsung pada usaha yang menggunakan ikan lele sebagai bahan baku.

5) Hasil penjualan bersih diberikan kepada masyarakat yang mengelola, sudah barang tentu untuk modal produksi selanjutnya perlu disisihkan. Dengan demikian, kegiatan budidaya ikan lele dapat mencapai keberlanjutan.

Kemudian, masyarakat juga diberi buku akuntansi untuk pencatatan pengelolaan dana secara sederhana, namun bermanfaat dalam memonitor usaha yang dijalankan.

\section{Budidaya Ikan Lele}

Ikan lele memiliki tingkat permintaan pasar yang tinggi. Hal ini sesuai dengan data Badan Pusat Statistik tahun (2015) dalam Ruherlistyani et al.
(2017) yang menyatakan bahwa pada tahun 2011-2015 menunjukkan kenaikan produksi sebesar $21,31 \%$ per tahun. Produksi ikan lele dari hasil budidaya nasional 2011 sebesar 337.557 ton, dan di tahun 2015 mengalami kenaikan menjadi 722.623 ton.

Ikan lele termasuk komoditas perikanan budidaya yang memiliki prospek baik selain ikan nila, gurame, dan patin. Berdasarkan Direktur Jenderal Perikanan Budidaya (2018), pertumbuhan rata-rata produksi ikan lele tahun 2015-2018 sebesar 56,32\% dengan produksi ikan lele nasional tahun 2018 mencapai 1,81 juta ton. Selain itu, walaupun target harapan konsumsi ikan hanya 30,14 kg/kapita/tahun namun pada kenyataannya sebesar $70 \%$ masyarakat Indonesia telah mengonsumsi ikan di atas angka pola harapan. Akan tetapi pada 2018 target harapan konsumsi ikan adalah 50,65 kg/kapita/ tahun harus tetap diperjuangkan untuk dicapai baik pada tahun tersebut, maupun pada tahuntahun berikutnya (Direktur Jenderal Perikanan Budidaya 2018; Tasyah et al., 2020).

Salah satu budidaya yang sedang menjadi idola masyarakat di Indonesia saat ini adalah ikan lele. Banyak faktor yang menjadikan ikan lele idola bagi masyarakat, di antaranya

1) Harga terjangkau.

2) Kandungan gizi yang tinggi.

3) Mudah didapatkan.

4) Citra masakan lele yang sudah menjadi makanan modern.

Bagi pelaku budidaya tentunya faktor tersebut menjadi semangat dan peluang tersendiri dalam rangka 
pengembangan usaha budidaya. Ikan lele merupakan ikan air tawar yang memiliki teknologi budidaya relatif mudah dikuasai oleh masyarakat dengan modal usaha yang cukup rendah, dan dapat dibudidayakan dalam kondisi lahan terbatas dengan menggunakan kolam terpal. Habitatnya di sungai dengan arus air yang perlahan seperti rawa, telaga, waduk, sawah yang tergenang air.

Pembesaran ikan lele yang inovatif dan produktif dapat dilakukan melalui sistem bioflock (Faridah et al., 2019; Latief et al., 2020). Sistem bioflock merupakan metode budaya ikan lele yang sudah cukup modern dan banyak digunakan oleh pelaku budidaya karena mampu mengurangi biaya produksi dan mampu meningkatkan produktivitas kolam (Sudaryati et al., 2017). Keistimewaan sistem kolam bioflock adalah waktu budidaya yang relatif singkat, modal relatif rendah, ramah lingkungan, dan hemat penggunaan air dan pakan (Fuadi et al., 2020). Metode bioflock kolam terpal adalah sistem pemeliharaan ikan lele dengan cara menumbuhkan mikroorganisme yang berfungsi mengolah limbah budidaya terutama pakan dan amonia yang bersifat racun bagi ikan lele dengan melakukan penambahan probiotik dan pemberian oksigen dengan aerator untuk mempercepat proses dekomposisi, sehingga limbah menjadi gumpalan kecil (floc) yang bermanfaat sebagai makanan alami ikan (Salamah \& Zulpikar 2020).

Cara budidaya ikan lele secara bioflock adalah suat sistem pemeliharaan ikan lele yang menumbuhkan suat mikroorganisme yang memiliki fungsi untuk mengelola limbah budidaya itu sendiri, sehingga menjadi gumpalan kecil (floc) yang dimanfaatkan langsung sebagai makanan alami. Pertumbuhan mikroorganisme ini tumbuh dengan cara memberikan probiotik atau kultur bakteri non patogen, dan meggunakan aerator penyuplai oksigen sekaligus untuk mengaduk air dalam kolam (Adharani et al., 2016). Keunggulan sistem biofloc seperti 1) kelangsungan hidup ikan sangat tinggi mencapai $90 \%$; 2) perbandingan pakan dengan pertambahan berat ikan lele 1,03 yang berarti menghemat biaya pakan; 3) padat tebar cukup tinggi yaitu mencapai 100 ekor $/ \mathrm{m}^{3}$, yang mengindikasikan tidak membutuhkan lahan yang luas untuk memulai budidaya ikan lele; 4) ikan lele pertumbuhannya cepat; 5) lama pemeliharaan sangat cepat \pm tiga bulan; 6) hemat air karena air tidak perlu sering diganti; 7) air kolam tidak berbau karena bakteri dapat memakan kotoran ikan (Siswoyo et al., 2020). Tujuan aerasi adalah membuang gas yang berbahaya seperti $\mathrm{N}_{2}$ dan $\mathrm{CO}_{2}$, serta untuk meningkatkan konsentrasi oksigen terlarut dalam air yang dapat meningkatkan status kesehatan ikan lele (Sumitro et al., 2020).

Satu siklus pemeliharaan ikan lele kurang lebih selama tiga bulan. Selama masa pemeliharaan ikan lele satu siklus, kegiatan yang dilakukan adalah:

1) Pengontrolan terhadap kualitas air

2) Kesehatan ikan

3) Kelulushidupan 
4) Pertumbuhan ikan lele sebagai data pendukung penilaian tingkat keberhasilan metode yang diterapkan.

\section{METODE PELAKSANAAN}

Metode pendekatan yang ditawarkan untuk menyelesaikan persoalan mitra yang telah disepakati bersama. Permasalahan pertama tentang kurangnya kemampuan guru/ calon guru dalam membuat proposal Penelitian Quasi Eksperimen:

1) Koordinasi dengan guru dan calon guru mengenai jadwal workshop yang tidak mengganggu jadwal rutin.

2) Metode yang digunakan yaitu:

- Workshop/ pelatihan dengan powerpoint yang sudah dibagikan sebelumnya, agar dapat dipelajari terlebih dahulu sesuai teori "readness" (Tim Pengabdian).

- Tanya jawab dan diskusi antara peserta dan narasumber (dari Tim Pengabdian yaitu Etin Solihatin).

- Latihan membuat proposal "Penelitan Quasi Eksperimen" (Tim Pengabdian).

- Pendampingan/ konsultasi sampai proposal jadi (draft) (Tim Pengabdian).

- Pendampingan mencari sumber dana dari Kemendikbud/ Pemda (Tim Pengabdian dan mahasiswa).

- Langkah evaluasi, setelah selesai kegiatan para guru/ calon guru diberi instrumen tentang pelaksanaan program, apa masalah yang harus segera diselesaikan pada tahap selanjutnya.

- Mitra mengisi instrumen kepuasan standar PPM pada link http://spm.unj.ac.id/?page_id=18 28.

- Semua peserta yang mengikuti kegiatan penuh diberi sertifikat.

- Peserta workshop yang aktif akan diberi reward (meski tidak mahal).

Permasalahan kedua tentang budidaya ikan lele dalam rangka meningkatkan pendapatan dan kesejahteraan masyarakat yaitu:

1) Koordinasi dengan masyarakat dan pihak kelurahan tentang jadwal kegiatan April - Agustus 2021.

2) Metode yang digunakan yaitu:

- Diskusi/ sharing pendapat untuk menyamakan persepsi mengenai budidaya ikan lele, pembagian tugas dan tanggung jawab.

- Praktek pembuatan kolam ikan lele dari terpal berkualitas baik

- Penanaman benih ikan lele sampai siap panen selama 3 bulan, dengan memberi pakan berupa pelet yang ukurannya disesuaikan dengan umur ikan.

- Monitoring dan kontrol rutin dari tim pengabdian masyarakat.

- Selama proses budidaya ikan lele, sudah diputuskan tentang pemasarannya baik ke pengepul maupun ke pasar.

- Pembukuan sederhana 
- Evaluasi budidaya ikan lele, agar kelebihan dan kekurangannya bisa dipantau, dan diperbaiki pada tahap selanjutnya.

Partisipasi Mitra selama pelaksanaan program pengabdian masyarakat:

- Mengikuti seluruh tahapan hingga selesai. Hal ini karena tim pengabdian masyarakat dari UNJ dan mitra telah bersepakat untuk menyelesaikan permasalahan yang ada, sesuai prioritas.

- Berpartisipasi aktif dalam setiap kegiatan pengabdian masyarakat baik secara daring maupun luring,

- Tidak ada program apapun yang berhasil tanpa semangat, komitmen, transparan, dan dukungan penuh dari kedua belah pihak yaitu mitra dan tim pengabdian kepada masyarakat UNJ.

Langkah evaluasi pelaksanaan program dilakukan secara menyeluruh dari tahap perencanaan, proses,output, dan melalui instrumen yang diberikan tim pengabdian, serta wawancara. Tim pengabdian masyarakat dan mitra wajib mengisi kepuasan standar ppm pada Link http://spm.unj.ac.id/?page_id=182 8. Selanjutnya, tim pengabdian masyarakat UNJ mendapat surat keterangan mitra tentang adanya peningkatan keberdayaan mitra sesuai permasalahan.

Keberlanjutan program di lapangan setelah kegiatan PPM selesai dilaksanakan melalui komunikasi yang tidak terputus antara tim pengabdian dan mitra, serta yang tidak kalah penting yaitu pembukuan sederhana. Kemudian hal berikutnya yang perlu diperhatikan adalah menyisihkan modal awal dan penyusutan untuk budi daya ikan lele demi keberlanjutan program. Tanggung jawab ini diserahkan pada ketua mitra dan warga yang mengelolanya demi keberlanjutan pendapatan.

\section{HASIL DAN PEMBAHASAN}

Pelaksanaan Workshop (Pelatihan)

Pembuatan Proposal "Penelitian Quasi Eksperimen" bagi Guru dan Calon Guru

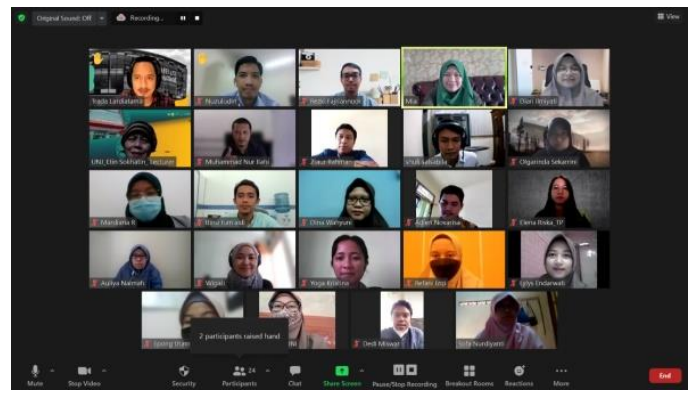

Gambar 1. Kegiatan Workshop Online melalui platform zoom meeting

Koordinasi dengan guru dan calon guru terkait jadwal workshop yang tidak mengganggu kegiatan rutin yaitu setiap hari Sabtu via zoom meeting. Setelah disepakati awal workshop/pelatihan, power point/materi diberikan terlebih dahulu agar peserta dapat belajar terlebih dahulu sebelum workshop/ pelatihan 
dimulai. Diberi waktu satu minggu untuk mempelajari. Hal ini sesuai teori "readness". Bulan Juni 2021 Minggu pertama, pada hari Sabtu tanggal 5 Juni 2021 workshop dilaksanakan secara daring dengan zoom meeting (gambar 1).

Acara workshop/pelatihan dilakukan diawali paparan materi dengan power point. Dilanjutkan dengan tanya jawab dan diskusi antara peserta dan nara sumber. Hal ini dilakukan agar suasana workshop aktif dan menyenangkan. Peserta aktif bertanya. Dengan demikian mereka belajar dengan menyenangkan.

Selanjutnya latihan membuat proposal "Penelitian Quasi Eksperimen". Atas kesepakatan bersama dalam situasi pandemi covid-19, proposal dibuat secara berkelompok. Minimal tim tiap kelompok memiliki draft proposal, dengan sistematika yang sudah disepakati sesuai aturan.
Pendampingan/konsultasi diberikan waktu hari Senin, Rabu, Sabtu, sesuai kesepakatan.

Semua peserta yang mengikuti kegiatan penuh diberi sertifikat. Peserta workshop yang aktif diberi reward (walalupun tdak memiliki nilai ekonomi yang tinggi).

Pelaksanaan Kedua: Budidaya Ikan Lele dalam Rangka Meningkatkan Pendapatan untuk Kesejahteraan

\section{Membuat Kolam Ikan Lele dari Bahan Terpal}

Kolam ikan lele terbuat dari bahan terpal. Hal ini untuk memudahkan pembuatan kolam ikan lele, dengan memanfaatkan pekarangan yang ada. Bahan penyusun kolam terdiri dari terpal, besi dan bambu sebagai kerangka, aerator untuk menjaga kandungan oksigen, tali, paku selang, dan pompa (tabel 1) .

Tabel 1. Bahan Penusun Kolam Lele

\begin{tabular}{lll} 
No & \multicolumn{1}{c}{ Bahan } & \multicolumn{1}{c}{ Banyaknya } \\
\hline 1 & Terpal yang sudah jadi ukuran $2 \mathrm{~m} \mathrm{x} \mathrm{1} \mathrm{m} \mathrm{x} \mathrm{0,5} \mathrm{m}$ & 5 buah \\
\hline 2 & Holo gal partisi & 20 batang \\
\hline 3 & Bambu & 12 batang \\
\hline 4 & Paku reng & $1 / 2 \mathrm{~kg}$ \\
\hline 5 & Tali tambang ukuran $1 \mathrm{~mm}$ & 1 gulung \\
\hline 6 & Aerator & $1 \mathrm{buah}$ \\
\hline 7 & Selang & $5 \mathrm{~m}$ \\
\hline 8 & Pompa bekas, masih bisa dipakai untuk penggantian air & $1 \mathrm{unit}$
\end{tabular}




\section{Deskripsi kolam}

Kolam terpal yang digunakan berukuran panjang 2 meter lebar 1 meter dan tinggi $1 / 2$ meter sebanyak 4 buah. Rangka tersebut dari besi hollow ketebalan $0,5 \mathrm{~mm}$ dengan panjang 4 meter, lebar 2 meter, tinggi 0,8 meter dilengkapi dengan sekat pemisah untuk setiap kolam berukuran $2 \times 1 \times 0,5 \mathrm{~m}$ dan penguat di bagian alas berupa palang memanjang setiap $0,7 \mathrm{~m}$, serta penguat dinding kolam tersebut dari bambu gombong yang dibelah menjadi 4 bagian dengan ukuran $4 \mathrm{~m}$ dan $2 \mathrm{~m}$.

Bibit ikan lele yang digunakan berukuran 5-7 cm berjumlah 1600 untuk 4 buah kolam yang dapat diperoleh dari penjual benih lele terdekat.

Penyiapan air kolam dilakukan dengan beberapa tahapan. menambahkan air sebanyak $0,6 \mathrm{~m}^{3}$ (ketinggian air $30 \mathrm{~cm}$ ) untuk masingmasing kolam. Menambahkan 125gr garam ikan yang diencerkan dengan 1 gayung air (1 L). Mencampurkan EM4 perikanan $(10 \mathrm{~mL})$, urea $1 / 4$ sendok makan $(2,5 \mathrm{~g})$, molase $(10 \mathrm{~mL})$, perasan $1 / 4$ lembar daun pepaya dengan 1 gayung air. Tahap berikutnya merupakan menyiapkan instalasi aerator dengan 2 titik semburan oksigen pada setiap kolam, yang dinyalakan untuk mempercepat pertumbuhan pertumbuhan mikroba. Setelah itu, melakukan inkubasi air selama 7-10 hari. Kemudian, setelah waktu inkubasi selesai tahap berikutnya merupakan tahap penanaman benih lele.

Tahap penebaran benih lele ukuran 5-7 cm dilakukan dalam beberapa tahapan. Benih lele dimasukkan dengan cara merendam kantung ke dalam kolam selama 30-45 menit, sehingga lele dapat mengurangi stres lele sebagai akibat dari perbedaan suhu. kemudian, kantung dibuka dan air kolam dimasukkan perlahan, hingga lele dapat keluar dari kantung secara alami. Jika lele diangkut dengan jerigen, metode alternatif lain dapat dilakukan dengan memasukan air kolam ke dalam jerigen menggunakan gayung secara perlahan. Pemberian makan dilakukan 12-18 jam setelah penebaran benih lele untuk menghindari kekeruhan air berlebih karena pakan tidak seluruhnya dikonsumsi ikan lele. Setelah itu, pemeliharaan dilakukan setiap hari hingga masa panen selama \pm tiga bulan. 


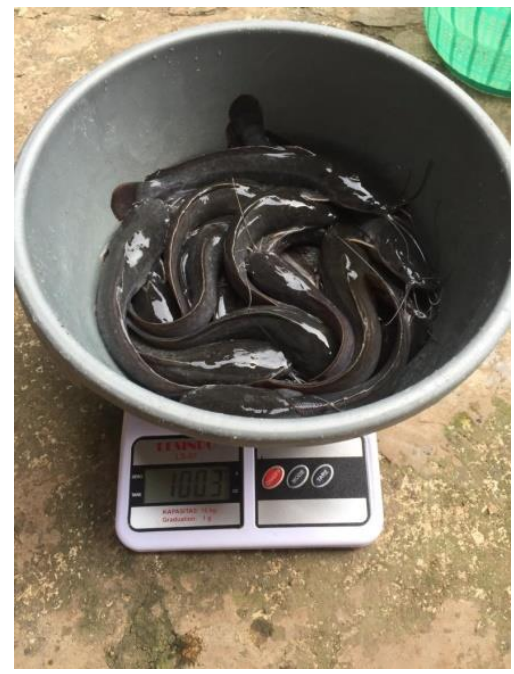

Gambar 2. Proses penimbangan bobot ikan lele

Proses pemeliharaan yang dilakukan berupa pemberian pakan dan pengecekan kondisi air, serta penyortiran ukuran ikan lele. Pada 12-18 jam setelah penanaman bibit lele dilakukan pemberian pakan Pf 1000, sebanyak 3 kali sehari yaitu pagi (07.00-07.30), siang (12.00-12.30) dan malam hari (21.00-21.30). Pakan yang digunakan untuk budi daya ikan lele pada kolam terpal adalah pakan terapung dengan bobot $3-5 \%$ dari bobot ikan lele (penimbangan dengan 10 sampel sebanyak 3 ulangan per kolam) (gambar 2). Pakan terapung digunakan pada budi daya lele pada kolam terpal untuk mengurangi pemberian pakan berlebih. Hal ini dikarenakan pemberian pakan berlebih pada kolam terpal memiliki risiko menurunkan kualitas air karena peningkatan amonia dan nitrit berlebih yang beracun bagi ikan (Mulyani et al., 2021).

Pemeliharaan dengan pemberian pakan PF 1000 dilakukan hingga ukuran 12-15 cm. Pengecekan kondisi air yang dilakukan adalah penggantian air sebanyak 30\% apabila air berbau. Kegiatan sortir dilakukan setelah 21 hari dan setiap 14 hari apabila pertumbuhan dirasa kurang seragam. Ikan lele yang memiliki pertumbuhan yang berbeda dipisahkan guna mengurangi tingkat kanibalisme.

Proses pemindahan menuju kolam pembesaran akhir dilakukan setelah lele mencapai ukuran $12-15 \mathrm{~cm}$. Kolam pembesaran yang digunakan terbuat dari terpal dengan ukuran $6,4 \times 1,6 \times 0,5 \mathrm{~m}^{3}$ hingga mencapai ukuran konsumsi (912 ekor per kg atau 6-8 ekor per $\mathrm{kg}$ ) yang disesuaikan dengan permintaan pasar. Pemberian pakan pada tahap ini menggunakan pakan Hi-Pro_zvitO 7811 (pakan lele masa produksi).

Kolam pembesaran awal digunakan kembali untuk pembesaran bibit lele ukuran 5-7 kembali sebanyak 400 ekor per kolam untuk siklus berikutnya. Hal ini bertujuan untuk menjaga siklus dan keberlanjutan dalam beternak ikan lele, sehingga dapat memenuhi kebutuhan pasar secara berkelanjutan. 


\section{PENUTUP}

Pertama, workshop/ pelatihan pembuatan proposal "Penelitian Quasi Eksperimen" dapat meningkatkan kemampuan guru/ calon guru dalam membuat draft proposal penelitian. Informasi dan praktek diberikan untuk mendapatkan persepsi yang sama, dan penyegaran pengetahuan mengenai penelitian quasi eksperimen. Diperlukan pendampingan/ konsultasi yang intensif, membantu mencari sumber rujukan, memilih artikel yang akan disitasi sesuai variabel pada judul, memilih masalah yang urgen dan mendesak untuk diteliti, mengikuti panduan penulisan proposal secara baik dan benar. Atas kesepakatan bersama, draft proposal dibuat secara berkelompok. Draft proposal dipresentasikan, untuk mendapat masukan. Dokumentasi kegiatan dan $Q R$ Code materi pembuatan proposal dapat dilihat pada platform YouTube https://www.youtube. $\mathrm{com} /$ watch? $v=\operatorname{ogfgRQJUE7} w$.

Kedua, budidaya ikan lele dalam rangka meningkatkan pendapatan untuk kesejahteraan masyarakat. Metode yang digunakan diskusi/ sharing dan praktek membuat kolam dari terpal yang sudah jadi, serta praktek penyemaian bibit ikan lele secara bioflock yaitu suatu sistem untuk menumbuhkan suatu mikroorganisme untuk mengelola limbah budidaya, menjadi gumpalan kecil (floc) yang dimanfaatkan langsung sebagai makanan alami. Aerator untuk menyuplai oksigen, sekaligus untuk mengaduk air dalam kolam. Dalam waktu \pm 3 bulan ikan lele dipanen. Pendapatan masyarakat meningkat (tadinya di-PHK sekarang memiliki pendapatan) untuk kesejahteraan. Dokumentasi kegiatan dan langkah budidaya lele dapat dilihat pada platform YouTube https://m.youtube. com $/$ watch $? v=$ G542rOJuzrc

\section{Ucapan Terima Kasih}

Ucapan terima kasih disampaikan kepada Fakultas Ilmu Sosial yang telah mendanai sepenuhnya kegiatan Pengabdian masyarakat sesuai surat perjanjian penugasan dalam rangka pelaksanaan pengabdian masyarakat dosen fakultas Nomor 62/P2M/FIS/IV/2021 pada 14 April 2021.

\section{DAFTAR PUSTAKA}

Adharani, Nadya, Kadarwan Soewardi, Agung Dhamar Syakti, and Sigid Hariyadi. 2016. "Water Quality Management Using Bioflocs Technology: Catfish Aquaculture (Clarias Sp.)." Jurnal Ilmu Pertanian Indonesia 21(1):35-40. doi: 10.18343/jipi.21.1.35.

Cresswell, Jhon W. 2017. Research Design Pendekatan Kualitatif, Kuantitatif, Dan Mixed Edisi Ketiga.

Direktur Jenderal Perikanan Budidaya. 2018. Peraturan Direktur Jenderal Perikanan Budidaya Nomor 65/PER-DJPB/2018.

Faridah, Faridah, Selvie Diana, and Yuniati Yuniati. 2019. "Budidaya Ikan Lele Dengan Metode Bioflok Pada Peternak Ikan Lele Konvesional." CARADDE: Jurnal Pengabdian Kepada Masyarakat 1(2):224-27. doi: 10.31960/caradde.v1i2.74.

Fuadi, Anwar, Muhammad Sami, and Usman Usman. 2020. "Teknologi 
Tepat Guna Budidaya Ikan Lele Dalam Kolam Terpal Metode Bioflok Dilengakapi Aerasi Nano Buble Oksigen." Jurnal Vokasi 4(1):39-45. doi: 10.30811/vokasi.v4i1.1819. Latief, Abdul, Agus Putra, Adi Bejo Suwardi, and Baihaqi. 2020. "Addition of Probiotic on Commercial Feed with Different Proteins on the Performance of Catfish (Clarias Sp.) Using Biofloc System." Acta Aquatica 4(2):180-86. doi:

10.37859/jpumri.v4i2.2103.

Maciejewski, Matthew L. 2020. "QuasiExperimental Design." Biostatistics and Epidemiology. doi: 10.1080/24709360.2018.1477468. Montgomery, Douglas C. 2012. Design and Analysis of Experiments Eighth Edition.

Mulyani, Urip, Wirda Hanim, and Endang Setiyowati. 2016. "Pengaruh Teknik Diskusi Kelompok Dalam Bimbingan Kelompok Terhadap Peningkatan Pemahaman Siswa Tentang Dimensi Seksualitas Manusia." Jurnal Bimbingan Konseling 5(1):116-25.

Mulyani, Yuniar, Ine Maulina, P. P. Bagaskhara, Aldhi Rahmandianto, Anqy ZA RIyanto, and RIzka Nurfadilah. 2021. "Education of Management Feeding in The Cultivation of Catfish for The Community of Raharja Village, Tanjungsari, Sumedang." Farmers Joournal of COmmunity Service 2(1):7-10.

Pratiwi, Dona Dinda. 2016.

"Pembelajaran Learning Cycle 5E Berbantuan Geogebra Terhadap Kemampuan Pemahaman Konsep Matematis." Al-Jabar : Jurnal
Pendidikan Matematika 7(2):191202. doi: 10.24042/ajpm.v7i2.34.

Purwanti, Ramadhani Dewi, Dona Dinda Pratiwi, and Achi Rinaldi. 2016. "Pengaruh Pembelajaran Berbatuan Geogebra Terhadap Pemahaman Konsep Matematis Ditinjau Dari Gaya Kognitif.” AlJabar: Jurnal Pendidikan Matematika 7(1):115-22. doi: 10.24042/ajpm.v7i1.131.

Ruherlistyani, Dwi Sudaryati, and Sucahyo Heriningsih. 2017. Budidaya Lele Dengan Sistem Kolam Bioflok. LPPM UPN VY.

Salamah, Salamah, and Zulpikar Zulpikar. 2020. "Pemberian Probiotik Pada Pakan Komersil Dengan Protein Yang Berbeda Terhadap Kinerja Ikan Lele (Clarias Sp.) Menggunakan Sistem Bioflok." Acta Aquatica: Aquatic Sciences Journal 7(1):2127. doi: 10.29103/aa.v7i1.2388.

Simamora, Roymond H. 2020.

"Pelatihan Komunikasi Efektif Untuk Meningkatkan Efikasi Diri Perawat Dalam Pelaksanaan Identifikasi Pasien.” Jurnal Ilmiah Kesehatan Masyarakat 12(1):4954.

Siswoyo, Bambang H., Uswatul Hasan, and M. Manullang. 2020.

"Budidaya Ikan Lele Dengan Teknologi Bioflok Di Keluarahan Nelayan Indah." Reswara: Jurnal Pengabdian Kepada Masyarakat 2(1):1-6.

Sudaryati, Dwi, Sucahyo Heriningsih, and Rusherlistyani Rusherlistyani. 2017. "Peningkatan Produktivitas Kelompok Tani Ikan Lele Dengan Teknik Bioflok." Jppm: Jurnal Pengabdian Dan Pemberdayaan Masyarakat 1(2):109. doi: 10.30595/jppm.v1i2.1695. Sumitro, Sumitro, Arfan Afandi, 
Kurniawan Wahyu Hidayat, and Rifqah Pratiwi. 2020. "Evaluasi Beberapa Desain Pipa Mikropori Sebagai Sistem Aerasi Dalam Budidaya Ikan Lele (Clarias Gariepinus) Intensif Berbasis Teknologi Bioflok." Journal of Aquaculture and Fish Health 9(2):114. doi: 10.20473/jafh.v9i2.16692.

Tasyah, Novira Nanda, Mugi Mulyono,
Moch Farchan, Amyda Suryati Panjaitan, and Effi Aftiani Thaib. 2020. "Performa Budidaya Ikan Lele Sangkuriang (Clarias Gariepinus) Sistem Bioflok Dengan Intervensi Grading." Jurnal Agroqua: Media Informasi Agronomi Dan Budidaya Perairan 18(2):168. doi: 10.32663/ja.v18i2.1297. 